\title{
STRUKTUR KOMUNITAS MOLUSKA DI PADANG LAMUN PERAIRAN PULAU BELITUNG PROVINSI BANGKA BELITUNG
}

\author{
COMMUNITY STRUCTURE OF MOLLUSCS AT SEAGRASS BEDS IN \\ BELITUNG ISLAND WATERS, BANGKA BELITUNG PROVINCE
}

\author{
Hendrik A.W. Cappenberg* dan Diah Anggraini Wulandari \\ Pusat Penelitian Oseanografi (P2O) - LIPI, Jakarta, 14430, Indonesia \\ "E-mail: hendrik_awc@yahoo.com
}

\begin{abstract}
The Belitung Island consists of small islands with seagrass area, which inhabited by species of mollusks but the diversity of in mollusk in these waters no yet widely known. Observations in Kelayang Island (BLTSO1 station), Kepayang Island (BLTSO2 station), Mendanau Island (BLTSO3 station), Sekutai Island (BLTS04 station), Sebongkok Island (BLTS05 station), Ruk Island (BLTS06 station) and Kalimambang Island (BLTSO7 station) was conducted on 29 August to 9 September 2018 to find out community structure and mollusks density. The method used was quadrant transect, starting from the edge of the beach perpendicular to the coast. From the results of the study, it was found 22 species of mollusk consisting of 10 species of bivalves class and 12 species of gastropods class. Anadara antiquata, Pinna bicolor and Gafrarium pectinatum from the bivalves class, and Lambis lambis and Strombus urceus from the gastropods class were having a relatively wide distribution. The highest mollusk density was found in station BLTSO6 (23.283 individu/ha) and the lowest was in Station BLTSO3 (283 individu/ha), respectively Isognomon isognomum was a species that dominated the sand substrate in BLTSO6. The value of species diversity index $\left(H^{\prime}\right)$ ranged from 2.42 to 3.52. This value indicated the diversity of mollusk species was of moderate condition. Evenness index $\left(J^{\prime}\right)$ ranged from 0.71 to 0.86 . From the results of this study, it can be concluded that the mollusk community in these waters is still in reasonably good condition.
\end{abstract}

Keywords: abundance, Belitung, community structure, distribution, mollusk seagrass beds

\begin{abstract}
ABSTRAK
Pulau Belitung memiliki banyak pulau-pulau kecil dengan tutupan lamun yang cukup bervariasi, tempat berbagai jenis moluska hidup, namun keanekaragaman moluska di perairan ini belum banyak diketahui. Penelitian di Pulau Kelayang (stasiun BLTS01), Pulau Kepayang (stasiun BLTS02), Pulau Mendanau (stasiun BLTS03), Pulau Sekutai (BLTS04), Pulau Sebongkok (stasiun BLTS05), Pulau Ruk (stasiun BLTS06) dan Pulau Kalimambang (stasiun BLTS07), telah dilakukan pada tanggal 29 Agustus hingga 9 September 2018. Tujuan dari penelitian ini, untuk mengetahui struktur komunitas dan kepadatan moluska. Metode penelitian yang digunakan adalah metode transek kuadran, yang dilakukan dari tepi pantai tegak lurus ke arah tubir. Dari hasil penelitian ini ditemukan sebanyak 22 jenis moluska yang terdiri dari 10 jenis dari kelas bivalvia dan 12 jenis dari kelas gastropoda. Anadara antiquata, Pinna bicolor dan Gafrarium pectinatum dari kelas bivalvia; Lambis lambis dan Strombus urceus dari kelas gastropoda memiliki penyebaran yang luas. Kepadatan moluska tertinggi terdapat di stasiun BLTS06 (23,283 individu/ha) dan terendah di stasiun BLTS03 (283 individu/ha). Isognomon isognomum merupakan jenis yang mendominasi stasiun BLTS06. Nilai indeks keanekaragaman jenis (H') berkisar antara 2,42-3,52 dan masuk dalam kategori keanekaragaman sedang. Indeks kemerataan jenis (J') berkisar antara 0,71-0,86. Hasil penelitian ini menunjukkan bahwa komunitas moluska di perairan ini masih berada dalam kondisi cukup baik.
\end{abstract}

Kata kunci: Belitung, kepadatan, moluska, padang lamun, sebaran, struktur komunitas 


\section{PENDAHULUAN}

Kabupaten Belitung merupakan bagian dari wilayah Provinsi Kepulauan Bangka Belitung. Memiliki banyak pulaupulau besar dan kecil, yang tersebar dari utara hingga barat dan diapit oleh Selat Karimata di sebelah timur dan Selat Gaspar di sebelah barat. Selain memiliki sumber daya mineral yang melimpah seperti timah, juga memiliki sumber daya perikanan yang menjadi salah satu mata pencaharian penduduk yang tinggal di wilayah pesisir pantai. Kawasan ini sering ditemukan beberapa ekosistem pesisir seperti rataan terumbu karang, padang lamun dan mangrove. Ekosistem ini menyediakan habitat, tempat berlindung, dan makanan bagi banyak organisme, termasuk beberapa jenis yang mendukung perikanan penting dekat pantai.

Padang lamun memiliki

keanekaragaman yang terbatas namun merupakan salah satu ekosistem paling produktif (Short et al., 2007). Ekosistem ini memiliki nilai ekologis dan ekonomi yang sangat besar karena dapat mensuplai karbon organik ke ekosistem sekitarnya, serta menyediakan makanan dan habitat bagi fauna tertentu, menjaga stabilitas sedimen, dan menjaga stabilitas garis pantai (Orth et al., 2006; Heck et al., 2008). Dengan sistem perakarannya yang menyilang, secara fisik tumbuhan lamun berperan penting sebagai pelindung pantai dari abrasi yang disebabkan oleh gelombang dan arus laut yang besar (Koch et al., 2006), menjaga stabilitas lingkungan, serta memberikan dukungan fisik dan biologis yang penting bagi komunitas lainnya (Gillanders, 2006).

Padang lamun berperan penting dalam menjaga kelestarian dan keanekaragaman biota laut (Adi, 2007), sebagai tempat memijah, daerah asuhan dan mencari makan bagi berbagai jenis biota seperti moluska (Helfman et al., 2009; CullenUnsworth and Unsworth, 2013; Urra et al., 2013; Kendrick et al., 2016), serta sebagai substrat bagi biota penempel dan makro fauna (Bujang et al., 2006). Moluska merupakan salah satu komponen utama di padang lamun, bersama-sama dengan polychaeta, crustasea, echinodermata serta makro fauna lainnya (Unsworth et al., 2007a, b; Vonk et al., 2008; Adulyanukosol and Poovachiranon, 2006), memiliki keanekaragaman jenis yang sangat tinggi, mencapai lebih dari 50.000 spesies (Khanna and Yadav, 2004).

Moluska merupakan salah satu kelompok hewan yang sangat sukses beradaptasi pada keragaman zona pasang surut dengan perubahan suhu yang ekstrim, serta ditemukan hidup pada berbagai tipe habitat mulai dari laut dalam, zona intertidal, air tawar dan darat (Vaghela and Kundu, 2011). Moluska berperan penting sebagai komponen dalam rantai makanan (Vaghela et al., 2013), baik sebagai pemangsa (predator), maupun yang dimangsa. Cara hidup moluska yang menempel, membenamkan cangkang atau menetap pada substrat (sesil), membuat kehadiran dan distribusinya sangat dipengaruhi oleh perubahan yang terjadi dalam ekosistem lingkungan (Hartoni dan Agussalim, 2013), dan sering digunakan sebagai indikator dalam menentukan tingkat pencemaran suatu perairan (Rachmawaty, 2011; Mendes et al., 2007). Faktor lingkungan lamun yang sangat bervariasi menjadi penyebab adanya perbedaan cara hidup dan penyebaran moluska. Rimpang, daun dan akar lamun dapat menyediakan habitat mikro yang berbeda bagi organisme lainnya, serta dapat memberikan perlindungan dari pemangsa (Attrill et al., 2000). Beberapa jenis moluska yang ditemukan pada ekosistem padang lamun memiliki nilai ekonomis penting, yang keberadaannya tergantung dari kondisi lamun dan tipe substratnya. Fredriksen et al. (2005); Hily et al. (2004) menyatakan bahwa banyak organisme dan moluska memakan bahan organik dan detritus hasil penguraian dari tumbuhan dan epifit pendukung serta partikel yang terdapat di antara daun lamun. 
Aktivitas manusia dalam memanfaatkan potensi sumberdaya perairan pesisir serta kegiatan antropogenik, seperti pengerukan, reklamasi, pengembangan resort, ataupun penggunaan jaring pantai untuk menangkap ikan dapat berdampak negatif bagi penurunan persentase tutupan lamun (Anonimous, 2017) dan keragaman biota seperti moluska yang hidup didalamnya. Hingga saat ini, berbagai penelitian tentang moluska telah banyak dilakukan di Indonesia (Cappenberg dan Panggabean, 2005; Dibyowati, 2009: Islami dan Mudjiono, 2009; Mudjiono, 2009; Arbi, 2010; Istiqlal et al., 2013), sehingga keberadaan jenis dan struktur komunitas moluska di sebagian wilayah pantai sudah dapat diketahui.

Penelitian moluska di kawasan pesisir pantai Pulau Belitung masih tergolong sedikit, oleh karena itu penelitian ini dilakukan dengan tujuan untuk mengetahui struktur komunitas moluska seperti keanekaragaman jenis, sebaran dan kepadatannya di ekosistem padang lamun. Penelitian ini merupakan yang pertama kali dilakukan dan diharapkan dapat mem-berikan tambahan informasi tentang keberadaan jenis-jenis moluska pada ekosistem padang lamun di perairan pantai Kabupaten Belitung serta dapat menjadi data dasar untuk penelitian selanjutnya.

\section{METODE PENELITIAN}

\subsection{Lokasi dan Waktu Penelitian}

Penelitian ini dilaksanakan dari tanggal 29 Agustus hingga 9 September 2018 di tujuh stasiun yang terletak di pesisir Pulau Kelayang (stasiun BLTS01), Pulau Kepayang (stasiun BLTS02), Pulau Mendanau (stasiun BLTS03), Pulau Sekutai (BLTS04), Pulau Sebongkok (stasiun BLTS05), Pulau Ruk (stasiun BLTS06) dan Pulau Kalimambang (stasiun BLTS07), yang memiliki tumbuhan lamun (Gambar 1). Pada masing-masing stasiun dilakukan transek kuadrat sepanjang $100 \mathrm{~m}$ yang disesuaikan dengan panjang rataan terumbu. Transek dilakukan tegak lurus garis pantai, dan dimulai dari tepi pantai hingga ke arah tubir pada saat air surut atau menjelang surut. Pengambilan sampel moluska dilakukan dengan menggunakan kuadrat berukuran $50 \quad \mathrm{~cm} \quad$ x $50 \quad \mathrm{~cm}$ (Rahmawati et al., 2017). Titik plot (kuadrat) pengamatan dilakukan pada setiap jarak $10 \mathrm{~m}$ sepanjang garis transek. Semua jenis moluska hidup yang terdapat dalam kuadrat diambil dan diawetkan dengan alkohol 70\%. Adapun jenis dan tutupan lamun serta tipe substrat sepanjang garis transek juga dicatat. Sampel moluska diidentifikasi di Laboratorium P2OLIPI, sampai pada tingkat jenis berdasarkan buku identifikasi Abbott and Dance (1990), Poutiers (1998) dan Dharma (2005).

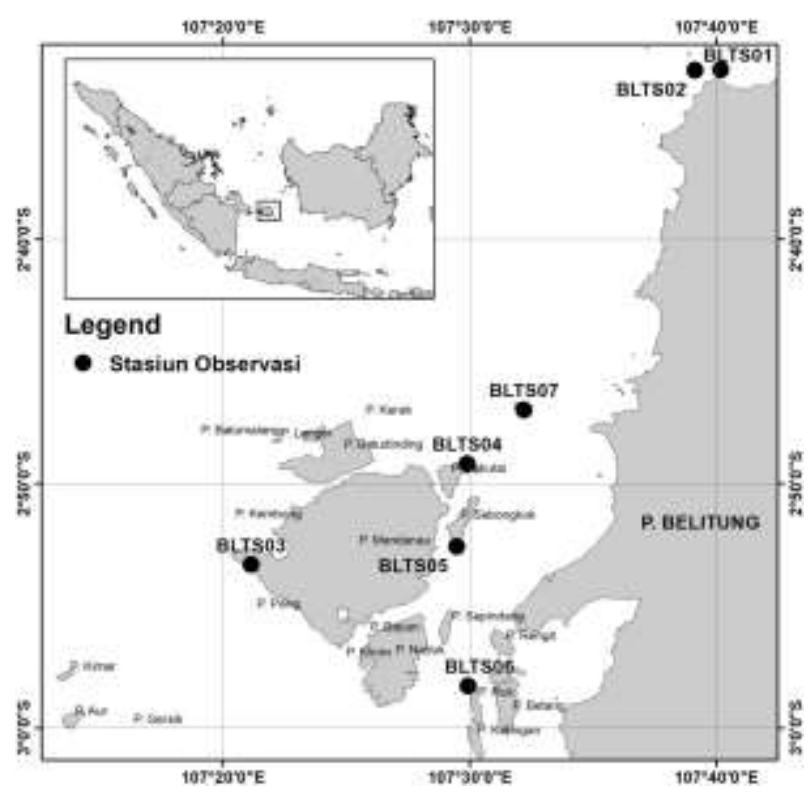

Gambar 1. Peta lokasi pengambilan sampel di perairan Pulau Belitung.

Analisis kemiripan komunitas moluska menggunakan Bray-Curtis, dan beberapa indeks struktur komunitas, seperti indeks keanekaragaman jenis (Shannon index) dan indeks kemerataan jenis (Evenness index) menggunakan software PRIMER (Plymouth Routines in Multivariate Ecological research) versi 5.1 (Clarke and Warwick 2001). 


\section{HASIL DAN PEMBAHASAN}

\subsection{Hasil}

\subsubsection{Kondisi Lokasi Penelitian}

Profil perairan pantai stasiun pengamatan dan sekitarnya umumnya landai, dengan tipe substrat yang terdiri dari pasir berlumpur, pasir halus, pasir kasar, patahan karang mati dan berbatu. Daerah ini memiliki tumbuhan pesisir seperti mangrove, lamun dan terumbu karang dengan persentase yang bervariasi. Ketiga ekosistem ini sering ditemukan dalam satu stasiun. Pada stasiun yang berada di sebelah utara Pulau Belitung seperti stasiun BLTS01 (Pulau Kelayang), BLTS02 (Pulau Kepayang), stasiun BLTS04 (utara Pulau Sekutai), BLTS05 (selatan Pulau Sebongkok), sebelah barat Pulau Ruk (BLTS06), Pulau Kalimambang (BLTS07), ekosistem padang lamun ditemukan dalam persentase tutupan bervariasi, serta diselingi dengan tumbuhan alga. Keberadaan mangrove dan lamun mampu mensuplai bahan organik yang tinggi pada substrat dasar perairan, yang mendukung pertumbuhan dan ke-langsungan hidup biota asosiasi (Bengen, 2002).

Keragaman jenis lamun yang ditemukan pada daerah pengamatan sebanyak 9 jenis, yaitu terdapat Thalassia hemprichii, Enhalus acoroides, Cymodocea rotundata, Halodule pinifolia, Cymodocea serrulata, Halophila ovalis, Halophila decipiens, Halophila spinulosa dan Halodule uninervis, dan didominasi oleh Thalassia hemprichii. Persentase tutupan lamun pada setiap stasiun pengamatan, berkisar antara $10,60-38,26 \%$, dengan tutupan rata-rata sebesar 18,08\%. Tutupan lamun tertinggi terdapat di stasiun BLTS07 $(38,26 \%)$ dan terendah di stasiun BLTS01 (10,60\%), sedangkan pada stasiun BLTS03 tidak ditemukan vegetasi lamun. Secara umum, persentase tutupan padang lamun di semua stasiun berada dalam kondisi jarang - sedang $(<50 \%)$ (Rahmawati el al., 2017), dan berada dalam kondisi kurang sehat $(<59,9 \%)$ (KMNLH No, 200 Tahun 2004). Tipe substrat pada stasiun BLTS01,
BLTS02, BLTS05 dan BLTS06 terdiri dari pasir lumpur - pasir dan pasir berbatu. Stasiun BLTS03 dan BLTS07 didominasi pasir, sedangkan pada stasiun BLTS04 didominasi oleh pasir dan patahan karang.

Kisaran suhu pada semua stasiun selama berlangsungnya pengamatan berkisar antara $29,70-30,26^{\circ} \mathrm{C}$, dan berada dalam kondisi normal bagi kehidupan moluska. Odum (1994) menyatakan kisaran suhu yang layak untuk pertumbuhan dan reproduksi bivalvia dan gastropoda berada antara 25 $32^{\circ} \mathrm{C}$. Salinitas merupakan faktor pembatas dalam distribusi organisme hidup pada ekosistem pesisir (Balasubramanian and Kannan, 2005). Nilai salinitas saat berlangsungnya pengamatan berkisar antara 26,00 - 26,5\%, dan berada dalam kisaran rendah, yang disebabkan oleh masuknya air tawar dari daratan melalui sungai karena adanya musim penghujan. Namun bila merujuk pada pernyataan Odum (1994), bahwa kisaran salinitas bagi kehidupan bivalvia dan gastropoda berada antara 0,5 $35 \%$, maka nilai salinitas pada setiap stasiun berada dalam kisaran yang normal.

Derajat keasaman $(\mathrm{pH})$ dasar perairan pada setiap stasiun berkisar antara $5,30-7,90 \mathrm{mg} / \mathrm{L}$, termasuk dalam kategori normal (Razak, 2003) dan berada dalam batas aman dan ideal bagi kehidupan biota (Susana, 2005). Fluktuasi nilai $\mathrm{pH}$ dalam perairan sangat berperan besar terhadap kehidupan organisme bentik (Kurihara et al., 2007; Beesley et al., 2008; Wood et al., 2008). Nilai $\mathrm{pH}$ perairan berperan penting dalam pem-bentukan cangkang biota laut, termasuk beberapa spesies moluska dan krustasea. Secara umum, nilai parameter kimia dan fisika pada setiap stasiun yang diamati berada dalam kategori kondisi perairan yang baik bagi kehidupan fauna bentik.

\subsubsection{Keragaman Jenis dan Kepadatan Individu Moluska}

Selama penelitian, dikumpulkan sebanyak 22 jenis moluska yang termasuk 
dalam 15 famili, mewakili 2 kelas, yaitu kelas bivalvia (10 jenis) dan gastropoda (12 jenis). Keragaman dan sebaran jenis moluska yang ditemukan pada setiap stasiun transek berkisar antara 7 hingga 20 jenis (Tabel 1). Keragaman jenis tertinggi terdapat di stasiun BLTS06, yaitu 20 jenis yang terdiri dari 9 jenis dari kelas bivalvia dan 11 dari kelas gastropoda, diikuti stasiun BLTS01 (19 jenis), terdiri dari 10 jenis kelas bivalvia dan 9 jenis dari kelas gastropoda dan BLTS04 sebanyak 17 jenis, terdiri dari 8 jenis bivalvia dan 9 jenis gastropoda, sedangkan keragaman paling rendah terdapat di stasiun BLTS03, yaitu 7 jenis (terdiri dari 4 jenis bivalvia dan 3 jenis gastropoda). Keragaman jenis moluska antara kelas bivalvia dan gastropoda yang ditemukan pada setiap stasiun memiliki jumah famili yang cukup berimbang, hanya pada stasiun BLTS02 kelas bivalvia memiliki jenis yang lebih beragam dari kelas gasropoda (Tabel 1).

Komposisi jenis moluska yang ditemukan pada semua stasiun menunjukkan, kelas bivalvia memiliki sebaran yang cukup luas dan dengan nilai frekuensi kehadiran yang tinggi dibandingkan kelas gastropoda. Persebaran yang luas dari kelas bivalvia, dan ditemukan hadir pada semua stasiun dengan nilai frekuensi kehadiran sebasar $100 \%$, diwakili oleh Anadara antiquata, Pinna bicolor, Gafrarium pectinatum, diikuti Pinna muricata dan Tapes literatus sebesar 85,71\%, Trachycardium rugosum dan Pitar citrinum (masing-masing 71,3\%), serta Isognomon isognomum $(57,14 \%)$ dan hanya dua jenis yang memiliki nilai frekuensi kehadiran < $50 \%$. Jenis-jenis ini hidup membenamkan cangkang ke dalam substrat lunak hingga berpasir, berbatu dan rataan terumbu pada zona pasang surut hingga kedalaman $20 \mathrm{~m}$ (Poutiers, 1998), sedangkan dari jenis-jenis gastropoda yang ditemukan, hanya Lambis lambis dan Strombus urceus ditemukan hadir pada semua stasiun dengan nilai frekuensi kehadiran sebesar $100 \%$, diikuti Rhinoclavis vertagus $(85,71 \%)$, serta Conus magus dan Tectus fenestratus masing-masing 71,43\%, dan enam jenis lainnya memiliki nilai frekuensi kehadiran < 50\% (Tabel 1).

Nilai kepadatan individu moluska pada semua stasiun penelitian cukup bervariasi, berkisar antara $283-23,2833$ individu/ha. Kepadatan tertinggi berada di stasiun BLTS06 (23,2833 individu/ha), diikuti stasiun BLTS01 (13,867 individu/ha), sedangkan kepadatan terendah terdapat di stasiun BLTS03 (283 individu/ha). Secara umum, kontribusi jenis-jenis dari kelas bivalvia cukup mempengaruhi tingginya nilai kepadatan moluska pada hampir semua stasiun dibandingkan kelas gastropoda.

\subsubsection{Keanekaragaman, Kemerataan dan Kekayaan Jenis}

Nilai keanekaragaman jenis terbentuk

dari kombinasi antara kekayaan dan kemeratan jenis. Besar kecilnya nilai keanekaragaman tidak hanya berhubungan dengan berapa banyak jenis yang ditemukan tapi juga berkaitan dengan seberapa meratanya jumlah individu pada masingmasing jenis tersebut. Keaneka-ragaman jenis merupakan komponen penting dalam komunitas, karena sering dikaitkan dengan fungsi dan potensi perubahannya (Stachowicz et al., 2007; Gamfeldt and Hillebrand, 2008). Hasil perhitungan nilai indeks keanekaragaman jenis (H') pada tujuh stasiun pengamatan berkisar antara 2,42 3,52, dan nilai keanekaragaman jenis tertinggi terdapat di stasiun BLTS04 $(3,52)$ dan yang terendah di stasiun BLTS06 $(2,42)$ (Tabel 2).

Kestabilan suatu komunitas dapat digambarkan dengan besar kecilnya nilai indeks kemerataan jenis ( $\mathrm{J}$ '), dan dapat dikatakan stabil, bila memiliki nilai kemerataan jenis mendekati 1 (satu). Sebaliknya semakin kecil nilai kemerataan jenis (mendekati 0), maka komunitas dikatakan labil. Tinggi rendahnya nilai kemerataan jenis mencerminkan seberapa merata individu-individu moluska terdistribusi secara berbeda pada setiap jenis dalam suatu komunitas. Nilai indeks 
kemerataan jenis berkisar antara $0,71-0,86$, nilai kemerataan jenis yang relatif rendah dan hanya stasiun BLTS06 (0.71) memiliki (Tabel 2).

Tabel 1. Keragaman jenis, kepadatan individu per hektar dan persentase kehadiran moluska pada masing-masing stasiun.

\begin{tabular}{|c|c|c|c|c|c|c|c|c|c|c|}
\hline \multirow[t]{2}{*}{ No. } & \multirow[t]{2}{*}{ Famili / Jenis } & \multicolumn{7}{|c|}{ BLTS } & \multirow{2}{*}{$\begin{array}{l}\text { Tot } \\
\text { Ind. }\end{array}$} & \multirow{2}{*}{$\begin{array}{c}\text { Kehadiran } \\
(\%)\end{array}$} \\
\hline & & 01 & 02 & 03 & 04 & 05 & 06 & 07 & & \\
\hline \multicolumn{11}{|c|}{ Kelas Bivalvia } \\
\hline \multicolumn{11}{|c|}{ Arcidae } \\
\hline 1 & Anadara antiquata & 683 & 17 & 33 & 50 & 317 & 2400 & 67 & 3567 & 100.0 \\
\hline \multicolumn{11}{|c|}{ II $\quad$ Cardiidae } \\
\hline 2 & Trachycardium rugosum & 3883 & 600 & 50 & 0 & 0 & 2017 & 83 & 6633 & 71.4 \\
\hline \multicolumn{11}{|c|}{ III Isognomonidae } \\
\hline 3 & Isognomon isognomum & 1083 & 17 & 0 & 67 & 0 & 9417 & 0 & 10583 & 57.1 \\
\hline \multicolumn{11}{|c|}{ IV Malleidae } \\
\hline 4 & Malleus malleus & 33 & 0 & 0 & 0 & 0 & 83 & 0 & 117 & 28.6 \\
\hline \multicolumn{11}{|c|}{ V Pinnidae } \\
\hline 5 & Pinna bicolor & 1783 & 200 & 17 & 233 & 33 & 533 & 17 & 2817 & 100.0 \\
\hline 6 & Pinna muricata & 2250 & 167 & 0 & 267 & 17 & 533 & 17 & 3250 & 85.7 \\
\hline \multicolumn{11}{|c|}{ VI Pteriidae } \\
\hline 7 & Pintada margaritifera & 467 & 50 & 0 & 100 & 0 & 0 & 0 & 617 & 42.9 \\
\hline \multicolumn{11}{|c|}{ VII Veneriidae } \\
\hline 8 & Grafarium pectinatum & 1400 & 617 & 117 & 333 & 167 & 1283 & 100 & 4017 & 100.0 \\
\hline 9 & Pitar citrinum & 200 & 17 & 0 & 150 & 17 & 583 & 0 & 967 & 71.4 \\
\hline 10 & Tapes literatus & 300 & 133 & 0 & 200 & 33 & 417 & 50 & 1133 & 85.7 \\
\hline \multicolumn{2}{|c|}{ Kepadatan Bivalvia/ha } & 12083 & 1817 & 217 & 1400 & 583 & 17267 & 333 & 33700 & \\
\hline$\overline{\mathrm{B}}$ & Kelas Gastropoda & & & & & & & & & \\
\hline \multicolumn{11}{|c|}{ Cerithidae } \\
\hline 1 & Cerithium nodulosum & 133 & 0 & 0 & 167 & 0 & 1367 & 0 & 1667 & 42.9 \\
\hline 2 & Rhinoclavis vertagus & 400 & 67 & 33 & 717 & 250 & 2667 & 0 & 4133 & 85.7 \\
\hline \multicolumn{11}{|c|}{ II Conidae } \\
\hline 3 & Conus magus & 83 & 0 & 0 & 17 & 33 & 117 & 33 & 283 & 71.4 \\
\hline \multicolumn{11}{|c|}{ III Cypraeidae } \\
\hline 4 & Cypraea sp. & 50 & 0 & 0 & 67 & 17 & 0 & 33 & 167 & 57.1 \\
\hline \multicolumn{11}{|c|}{ IV Fasicolaridae } \\
\hline 5 & Pleuroploca filamentosa & 167 & 0 & 0 & 0 & 0 & 167 & 0 & 333 & 28.6 \\
\hline \multicolumn{11}{|c|}{ V Neritidae } \\
\hline 6 & Nerita sp. & 150 & 0 & 0 & 0 & 0 & 117 & 0 & 267 & 28.6 \\
\hline \multicolumn{11}{|c|}{ VI Strombidae } \\
\hline 7 & Lambis lambis & 250 & 100 & 17 & 150 & 17 & 267 & 233 & 1033 & 100.0 \\
\hline 8 & Strombus urceus & 500 & 183 & 17 & 283 & 67 & 517 & 433 & 2000 & 100.0 \\
\hline \multicolumn{11}{|c|}{ VII Potamididae } \\
\hline 9 & Terebrali sulcata & 0 & 0 & 0 & 683 & 50 & 467 & 0 & 1200 & 42.9 \\
\hline \multicolumn{11}{|c|}{ VIII Trochidae } \\
\hline 10 & Tectus fenestratus & 50 & 33 & 0 & 67 & 17 & 217 & 0 & 383 & 71.4 \\
\hline 11 & Trochus niloticus & 0 & 0 & 0 & 17 & 0 & 67 & 0 & 83 & 28.6 \\
\hline 12 & Trochus radiatus & 0 & 0 & 0 & 0 & 0 & 50 & 0 & 50 & 14.3 \\
\hline
\end{tabular}




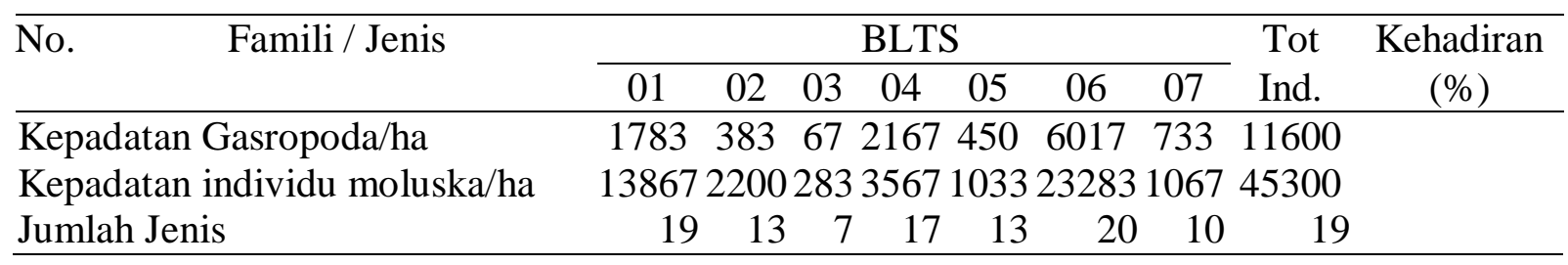

Tabel 2. Struktur komunitas moluska pada masing-masing stasiun.

\begin{tabular}{lccccccc}
\hline Struktur Komunitas & BLTS01 & BLTS02 & BLTS03 & BLTS04 & BLTS05 & BLTS06 & BLTS07 \\
\hline Keanekaragaman $\left(\mathrm{H}^{\prime}\right)$ & 3.29 & 2.90 & 2.42 & 3.52 & 2.87 & 3.06 & 2.57 \\
Kemerataan $\left(\mathrm{J}^{\prime}\right)$ & 0.77 & 0.78 & 0.86 & 0.86 & 0.76 & 0.71 & 0.77 \\
\hline
\end{tabular}

\subsubsection{Kemiripan jenis antar stasiun}

Perhitungan nilai kemiripan/ kesamaan antar stasiun penelitian dilakukan berdasarkan jumlah jenis moluska. Nilai kesamaan jenis moluska yang ditemukan antar kelompok stasiun pengamatan cukup tinggi $(<50 \%)$. Semakin tinggi nilai kesamaan jenis maka semakin besar peluang untuk mendapatkan jenis-jenis yang sama pada stasiun yang berbeda. Sebaliknya, semakin rendah nilai kesamaan jenis, maka kecil peluang untuk mendapatkan jenis moluska yang sama antar stasiun tersebut. Hasil perhitungan menunjukkan stasiun BLTS01 dan BLTS06, membentuk satu kelompok (cluster) dengan nilai kesamaan tertinggi sebesar $87,18 \%$. Kelompok lainnya terdiri dari stasiun BLTS04, BLTS05 dan BLTS02 dengan nilai kesamaan jenis sebesar $76,95 \%$, sedangkan kelompok berikutnya terdiri dari stasiun BLTS03 dan BLTS07 $(70,59 \%)$ (Gambar 2). Dua komunitas dikatakan sama dan masuk dalam kategori tinggi, jika memiliki nilai kemiripan (similarity) atau kesamaan antara $61-90 \%$ (Odum, 1994).

\subsection{Pembahasan}

Moluska merupakan salah satu kelompok dominan di komunitas laut, berkontribusi terhadap keanekaragaman hayati lokal dan mewakili sumber makanan penting untuk tingkat trofik yang lebih tinggi (Ballesteros, 2006; Raso et al., 2010), mampu hidup pada berbagai tipe habitat. Penelitian ini menunjukkan bahwa, fauna moluska di padang lamun perairan Pulau Belitung, secara umum cukup beragam (22 jenis) serta memiliki distribusi yang merata.

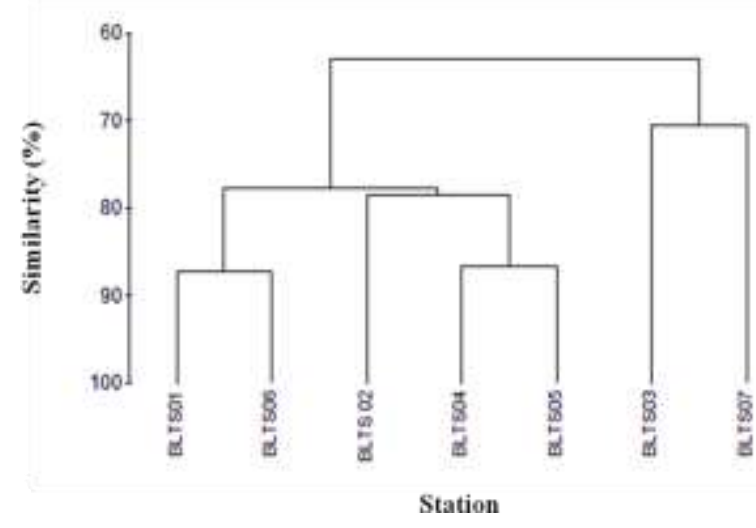

Gambar 2. Analisa kluster berdasarkan jumlah jenis moluska pada setiap stasiun.

Kehadiran moluska dalam keragaman jenis yang tinggi umumnya ditemukan pada stasiun-stasiun yang terdapat vegetasi lamun, dengan habitat yang heterogen. Habitat yang kompleks memiliki kekayaan jenis, keragaman dan kelimpahan individu yang tinggi (Gratwicke and Speight, 2005; Fredriksen et al., 2010), sedangkan keragaman jenis dan jumlah individu moluska yang rendah terdapat pada stasiun BLTS03, yang memiliki substrat homogen dan tidak memiliki vegetasi lamun serta didominasi oleh substrat pasir. Rendahnya keragaman jenis dan jumlah individu fauna moluska pada stasiun tersebut, diduga 
dipengaruhi oleh kondisi fisik lingkungan sebagai habitat untuk berlindung dari pemangsa dan ketersediaan makanan/ nutrien yang terbatas. Kehilangan padang lamun dapat memiliki konsekuensi penting dalam menjaga keanekaragaman hayati dan produktivitas perairan pesisir (Orth et al., 2006; Rueda et al., 2009), dan kelestarian biota akan terancam (Kusnadi et al., 2008). Aktivitas yang berlebihan dari kegiatan manusia pada perairan pesisir, menyebabkan hilangnya lamun dengan cepat (Short et al., 2006b) dan dapat menyebabkan rendahnya keragaman jenis. Kondisi ini menunjukan bahwa keberadaan ekosistem lamun dan variasi tipe substrat memiliki pengaruh yang besar terhadap keanekaragaman dan sebaran jenis moluska.

Keragaman moluska yang didapat dalam pengamatan ini relatif lebih tinggi dari hasil pengamatan Yuniarti (2012) di pesisir Glayem Juntinyuat Indramayu yang mendapatkan 15 jenis. Septiana (2017) di pantai pasir putih, Lampung Selatan mendapatkan 9 jenis, namun lebih rendah dibandingkan dengan hasil penilitian Cappenberg (2002) di Teluk Lampung, mendapatkan 65 jenis moluska; Cappenberg dan Panggabean (2005) di Gugus Pulau Pari, Kepulauan Seribu mendapatkan 45 jenis; Mudjiono (2007) di perairan Teluk Klabat, Provinsi Bangka Belitung dan Pulau Sembilan, yang mendapatkan 105 jenis; Irawan (2008) di Pulau Burung dan Pulau Tikus, Gugus Pulau Pari, menemukan 47 jenis; Dibyowati (2009) di sepanjang pantai Carita, Pandeglang, Banten menemukan 34 jenis dan penelitian Mudjiono (2009) di Kepulauan Natuna mendapatkan 83 jenis. Perbedaan keragaman dan komposisi jenis moluska antara lokasi dapat saja disebabkan oleh luas tutupan lamun, variasi tipe substrat, dan musim (Islami, 2012), kondisi lingkungan dan hidrologis perairan seperti intensitas cahaya, suhu, salinitas dan makanan (Cox and Moore, 2002).

Sebaran yang merata dari jenis-jenis moluska kelas bivalvia dengan nilai persentase yang besar, umumnya > 50\% (Tabel 1). Hal tersebut didukung oleh tipe substrat yang relatif sama pada hampir semua stasiun yang didominasi oleh pasir lumpur dan pasir (heterogen) serta adanya lamun sebagai mikrohabitat ideal bagi bivalvia (Short et al., 2007). Sedangkan, sebaran yang luas dari kelas gastropoda diwakili oleh genus Strombus dan Lambis dari famili Strombidae. Kedua genus ini ditemukan pada semua stasiun, dengan substrat lumpur berpasir, pasir hingga patahan karang (rubble). Kedua jenis ini umumnya ditemukan hidup pada zona intertidal dan sublitoral hingga kedalaman $40 \mathrm{~m}$ (Poutiers, 1998). Kelompok ini mendiami padang lamun dan memakan alga atau material detritus pada substrat berlumpur, berpasir atau pecahan karang, dan cenderung berkelompok dalam jumlah yang melimpah pada kondisi lingkungan-nya sesuai (Cob et al., 2014). Fauna moluska yang ditemukan dalam pengamatan ini merupakan jenis-jenis yang umum, serta mudah ditemukan hidup pada zona pasang surut (intertidal), dan tersebar luas di perairan pantai Indonesia maupun Indo-Pasifik barat (Dharma, 2005).

Nilai kepadatan individu moluska yang tinggi pada stasiun BLTS06 (Tabel 1), sangat dipengaruhi oleh besarnya kontribusi dari kelas bivalvia, (17267 individu/ha) dibandingkan kelas gastropoda (6017 individu/ha). Jenis-jenis dari kelas bivalvia yang memiliki kepadatan tertinggi pada stasiun ini diwakili oleh Isognomon isognomum yaitu sebesar 9417 individu/ha diikuti oleh Anadara antiquata (2400 individu/ha), Trachycardium rugosum (2017 individu/ ha) dan Gafrarium pectinatum (1283 individu/ha), keempat jenis ini bersama-sama hadir sebesar $59,41 \%$ dari nilai kepadatan individu yang ditemukan pada stasiun tersebut. Kontribusi terhadap tingginya nilai kepadatan pada stasiun BLTS01, juga dipengaruhi oleh kehadiran Trachycardium rugosum (3883 individu/ ha), Pinna muricata (2250 individu/ha) dan Pinna bicolor (1783 individu/ha). Ketiga jenis ini 
memiliki kontribusi sebesar $57,09 \%$ dari nilai kepadatan pada stasiun tersebut. Begitu juga pada stasiun BLTS02, nilai kepadatan dipengaruhi oleh kehadiran Trachycardium rugosum (600 individu/ha) dan Gafrarium pectinatum (617 individu/ha), atau sebesar $55,30 \%$ terhadap tingginya nilai kepadatan pada stasiun tersebut. Sedangkan, kepadatan terendah terdapat di stasiun BLTS03 (283 individu/ha), dan kontribusi kelas bivalvia juga relatif lebih tinggi dibandingkan kelas gastropoda. Kepadatan dan sebaran jenisjenis bivalvia yang tinggi ini berhubungan erat dengan ketersediaan makanan/nutrien, stabilitas substrat dan intensitas gelombang (Vaghela et al., 2013). Vegetasi lamun dan tipe substrat yang stabil merupakan perangkap nutrien yang baik, tempat berlindung dan mencari makan bagi beberapa organisme termasuk bivalvia (Riniatsih dan Munasik, 2017), yang mendapatkan makanan dengan menyaring dari kolom air dan atau substrat (filter feeder dan detritus feeder).

Kontribusi kelas gasropoda juga terlihat pada stasiun BLTS04, dimana nilai kepadatan ini dipengaruhi oleh kehadiran Rhinoclavis vertagus (717 individu/ha) dan Terebrali sulcata (683 individu/ha), atau sebesar 39,25\% dari nilai kepadatan moluska pada stasiun tersebut. Begitu juga dengan stasiun BLTS07, kehadiran Strombus urceus (433 individu/ha) dan Lambis lambis (233 individu/ha) memberikan kontribusi sebesar $62,50 \%$ terhadap nilai kepadatan pada stasiun tersebut. Keempat jenis ini termasuk dalam kelompok herbivora yang mengkonsumsi lamun dan alga (Poutiers, 1998), yang tumbuh dengan cukup baik pada kedua stasiun tersebut. Berdasarkan cara makannya, sebagian besar jenis-jenis moluska dari kelas gastropoda yang ditemukan dalam pengamatan ini termasuk dalam kelompok herbivora, sedangkan yang bersifat karnivora hanya diwakili oleh Conus magus dan Pleuroploca filamentosa. Kedua jenis ini ditemukan dalam jumlah individu yang sangat sedikit dengan sebaran yang sangat terbatas/ sempit dan hanya ditemukan pada dua stasiun (Tabel 1).

Nilai kepadatan individu moluska dalam pengamatan ini lebih rendah dari hasil pengamatan Cappenberg dan Panggabean (2005), di perairan terumbu karang pulau Seribu yang berkisar antara 16,000 - 91,000 individu/ha; Cappenberg (2006) di Kepulauan Derawan berkisar antara 23,700 69,700 individu/ha. Perbedaan nilai kepadatan individu dapat disebabkan oleh ada tidaknya tumbuhan lamun, kompleksitas perairan, seperti tipe substrat, ketersediaan makanan maupun faktor fisikakimia dan biologi, yang saling ketergantungan (Dibyowati, 2009; Ruswahyuni, 2010). Kehadiran lamun dapat menjadi tempat menempelnya mikroalga, makroalga dan hewan kecil yang berfungsi sebagai makanan bagi banyak organisme, serta sebagai produsen utama yang menghasilkan oksigen terlarut bagi organisme laut dan muara (Ogawa et al., 2011 dalam Fortes, 2012).

Hasil analisis nilai indeks keanekaragaman jenis (H') moluska pada semua stasiun berada pada kisaran 2,42 3,52. Secara umum, nilai-nilai ini mencerminkan bahwa fauna moluska pada semua stasiun, berada dalam kriteria keanekaragaman jenis yang sedang (Daget, 1976). Hanya pada stasiun BLTS03 yang memiliki nilai keanekaragaman jenis yang rendah. Rendahnya nilai ini bukan karena adanya dominansi individu pada jenis-jenis tertentu, tetapi dipengaruhi oleh sedikitnya fauna moluska yang ditemukan pada stasiun tersebut, sedangkan tingginya nilai keanekaragaman jenis pada stasiun BLTS04, selain disebabkan oleh banyaknya jenis yang ditemukan, juga dipengaruhi oleh jumlah individu yang terdistribusi cukup proporsional pada setiap jenis yang diwakili. Kondisi ini didukung dengan nilai indeks kemerataan jenis ( $\mathrm{J}$ ') yang tinggi yang juga ditemukan pada stasiun tersebut, sedangkan nilai kemerataan jenis terendah terdapat di stasiun BLTS06 (Tabel 2). Rendahnya nilai ini disebabkan oleh adanya dominansi 
individu dari Isognomon isognomum yang dicatat sebesar $40,44 \%$ dari total individu pada stasiun tersebut. Cara hidup yang berkelompok menunjukkan kecenderungan yang kuat dalam berkompetisi, terutama untuk mendapatkan makanan. Adanya dominansi individu pada satu atau beberapa jenis tertentu mencerminkan komunitas berada dalam kondisi labil (Odum, 1971). Daget (1976), juga menyatakan jika nilai J' < 0,75, maka komunitas labil, dengan demikian dapat dikatakan bahwa komunitas moluska pada stasiun BLTS06 berada dalam kondisi labil atau tidak stabil, sedangkan enam stasiun lainnya memiliki nilai kemerataan jenis lebih sebesar dari 0,75, dan berada dalam kondisi komunitas yang stabil (Daget, 1976).

Tingginya nilai kemiripan jenis pada stasiun BLTS01 dan BLTS06 (87,18\%), menunjukkan bahwa peluang mendapatkan jenis-jenis moluska yang sama antar kedua stasiun tersebut sangat besar. Dari $19-20$ jenis moluska yang ada pada kedua stasiun tersebut, ditemukan sebanyak 17 jenis yang sama. Walaupun letak kedua stasiun sangat berjauhan, namun memiliki banyak kesamaan seperti tipe substrat dan jenis-jenis lamunya. Hal ini didukung dengan nilai-nilai indeks keanekaragaman dan kemerataan jenis yang berimbang antar kedua stasiun tersebut (Tabel 2). Pengelompokan pada stasiun BLTS04, BLTS05 dan BLTS02 dengan nilai kesamaan jenis sebesar $76,95 \%$, juga menunjukkan bahwa dari $13-17$ jenis moluska yang berada pada ketiga lokasi tersebut ditemukan sebanyak 10 jenis yang sama. Sedangkan pada stasiun BLTS03 dan BLTS07 (70,59\%) (Gambar 6), ditemukan sebanyak 6 jenis yang sama dari jumlah jenis moluska yang ada pada kedua stasiun tersebut (7 dan 10 jenis).

Besarnya nilai persentase kesamaan jenis antar stasiun dipengaruhi oleh kehadiran jenis-jenis moluska dari kelas bivalvia dibandingkan gastropoda. Kondisi ini disebabkan oleh kemiripan tipe substrat pada setiap stasiun yang didominasi oleh pasir lumpur - pasir, yang merupakan mikrohabitat ideal bagi kehidupan kelas bivalvia. Substrat pasir halus mempunyai retensi air yang mampu menampung lebih banyak air dan memudahkan organisme untuk menggali, sehingga pada daerah pantai berpasir halus banyak ditemukan organisme dibandingkan pantai berpasir kasar (Nugroho, 2012). Banyaknya jenis-jenis moluska dari kelas bivalvia yang ditemukan hidup pada substrat lunak berhubungan dengan perilaku dan cara makannya (filter feeder), yang mana lebih aktif pada substrat lunak dibandingkan substrat kasar. Islami dan Mudjiono (2009) menyatakan bahwa tekstur substrat me-rupakan salah satu faktor ekologis utama yang mempengaruhi kelimpahan dan penyebaran makrozoobentos. Keragaman dan jumlah individu moluska dapat juga dipengaruhi oleh lama air pasang meng-genangi lokasi tersebut. Seluruh hewan intertidal, baik hewan pemakan tumbuhan (herbivora), pemakan bahan-bahan ter-saring (filter feeder), pemakan detritus (detrivor) maupun predator (carnivora) aktif melakukan kegiatan makan jika tubuhnya terendam air (Nybakken, 1992).

Keragaman dan komposisi jenis yang ditemukan pada setiap stasiun di padang lamun daerah pengamatan, mencerminkan bahwa lingkungan/ruang dan makanan masih cukup tersedia bagi kehadiran jenis-jenis moluska untuk hidup dan berkembang. Kondisi ini ditunjukkan dengan besaran nilai ekologis yang didapat. Namun nilai-nilai ini bersifat temporal, yang dapat menjadi lebih tinggi atau rendah, tergantung ada tidaknya pengaruh yang diterima lingkungan baik secara alami ataupun antropogenik, seperti penangkapan ikan yang berlebihan, konstruksi dan reklamasi yang dapat merusak padang lamun dan ekosistem sekitarnya secara langsung. Konsekuensi paling serius dari aktivitas manusia di perairan pesisir adalah rusaknya habitat yang berdampak buruk dan permanen pada ekosistem pesisir (Vaghela et al., 2013). 


\section{KESIMPULAN}

Moluska yang ditemukan selama pengamatan terdiri dari 22 jenis mewakili 15 famili. Kelas bivalvia sangat ber-kontribusi terhadap tingginya nilai kepadatan individu moluska. Anadara antiquata, Pinna bicolor dan Gafrarium pectinatum (kelas Bivalves), serta Lambis lambis dan Strombus urceus (kelas Gastropoda) merupakan jenis-jenis dengan penyebaran yang luas, sedangkan Isognomon isognomum (Isognomonidae), Trachycardium rugosum (Cardiidae) dan Cerithium nodulosum (Cerithidae) memiliki jumlah individu yang melimpah. Nilai ekologis dalam penelitian ini menunjukkan bahwa komunitas moluska berada dalam kondisi keanekaragaman jenis yang sedang dan kemerataan yang stabil serta memiliki kemiripan jenis antar stasiun yang cukup merata. Kondisi ini mencerminkan bahwa keberadaan padang lamun penting bagi keanekaragaman dan persebaran jenis-jenis moluska. Ini merupakan penelitian kuantitatif pertama berdasarkan fauna moluska yang terkait dengan padang lamun pada daerah perairan Kabupaten Belitung, sehingga dapat digunakan sebagai studi dasar untuk melakukan penelitian selanjutnya.

\section{UCAPAN TERIMA KASIH}

Penulis mengucapkan terima kasih kepada bapak Ir. Suyarso selaku koordinator Penelitian Proyek Monitoring Kesehatan Terumbu Karang dan Ekosistem Terkait Lainnya (Coremap-CTI) di perairan Kabupaten Belitung, Provinsi Bangka Belitung, yang memberikan dukungan dan mengijinkan menggunakan data moluska untuk dianalisa dalam tulisan ini.

\section{DAFTAR PUSTAKA}

Abbott, R.T. and P. Dance. 1990. Compendium of Seashell. Crawford House Pres. Australia. 411 p.
Adi, W. 2007. Komposisi dan kelimpahan larva dan juvenil ikan yang berasosiasi dengan tingkat kerapatan lamun yang berbeda di Pulau Panjang Jepara. J. Sumberdaya Perairan, 1(1): 7-11.

http://journal.ubb.ac.id/index.php/aku atik/article/view/360

Adulyanukosol K. and S. Poovachiranon. 2006. Dugong (Dugong dugon) and seagrass in Thailand: present status and future challenges. In: Proceedings of the $3^{\text {rd }}$ International Symposium on SEASTAR 2000 and Asian Bio-logging Science (The $7^{\text {th }}$ SEASTAR 2000 workshop). Kyoto University, Kyoto. 41-50 pp.

Anonimous. 2017. Monitoring kesehatan terumbu karang dan ekosistem terkait di Kabupaten Belitung. Program Coremap-CTI. Coral Reef Information and Training Center. Pusat Penelitian Oseanologi-LIPI, Jakarta. Hlm:87.

Arbi, U.Y. 2010. Moluska di pesisir barat perairan Selat Lembeh, Kota Bitung, Sulawesi Utara. J. Bumi Lestari, 10(1): 60-68.

https://ojs.unud.ac.id/index.php/blje/a rticle/ view/106/89

Attrill, M.J., J.A. Strong, and A.A. Rowden. 2000. Are macroinvertebrate communities influenced by seagrass structural complexity? Ecography, 23: 114-121.

https://www.jstor.org/stable/3682873 ?seq=1\#page_scan_tab_contents

Balasubramanian, R. and L. Kannan. 2005. Physicochemical characteristics of the coral reef environs of the Gulf of Mannar Biosphere Reserve, India. Int J. Ecol. Environ. Sci., 31(3): 265271.

Ballesteros, E. 2006. Mediterranean coralligenous assemblages: A synthesis of present knowledge. Oceanography and Marine Biology: An Annual Review, 44: 123-195. 
Beesley, A., D.M. Lowe, C.K. Pascoe, and S. Widdicombe. 2008. Effects of $\mathrm{CO}_{2-}$ induced seawater acidification on the health of Mytilus edulis. Climate Research, 37: 215-225. https://doi.org/10.3354/cr00765

Bengen, D.G. 2002. Pedoman teknis pengenalan dan pengelolaan ekosistem mangrove. Bogor. Pusat Kajian Sumberdaya Pesisir dan Laut (PKSPL) IPB. Hlm: 88.

Bujang, J.S., M.H. Zakaria and A. Arshad. 2006. Distribution and significance of seagrass ecosystems in Malaysia. Aquatic Ecosystem Health and Management, 9(2): 203-214. https://doi.org/10.1080/14634980600 705576

Cappenberg, H.A.W. 2002. Komunitas moluska di perairan Teluk Lampung, Provinsi Lampung. Dalam: Perairan Indonesia, Biologi, dan Lingkungan (Ruyitno, A. Aziz dan Pramudji. eds.). Pusat Penelitian dan pengembangan Oseanografi-LIPI. Jakarta. Hlm.: 89-99.

Cappenberg, H.A.W. dan M.G.L. Panggabean. 2005. Moluska di perairan terumbu Gugus Pulau Pari, Kepulauan Seribu, Teluk Jakarta. Oseanologi dan Limnologi di Indonesia, 37: 69-80.

http://oseanografi.lipi.go.id/perpustak aan/repository/showpdf/643

Cappenberg, H.A.W. 2006. Pengamatan komunitas moluska di perairan Kepulauan Derawan, Kalimantan Timur. Oseanologi dan Limnologi di Indonesia, 39: 75-87.

Clarke, K.R. and R.M. Warwick. 2001. Change in marine communities: An approach to statistical analysis and interpretation. ( $2^{\text {nd }}$ ed.). Primer-E Ltd. Plymouth marine laboratory, UK. 175 p.

Cob, Z.C., A. Arshaad, J.S. Bujang and M.A. Ghaffar. 2014. Spatial and temporal variations in Strombus canarium
(Gastropoda: Strombidae) abundance at Merambong Seagrass bed, Malaysia. Sains malaysiana, 43(4): 503-511.

Cox, C.B. and P.D. Moore. 2002. Biogeography: An Ecological and Evolutionary Approach (6 $6^{\text {th }}$ ed.). Blackwell Science Ltd. Oxford. 2: 98 p.

Cullen-Unsworth, L. and R. Unsworth. 2013. Seagrass meadows, ecosystem services, and sustainability. $J$. Environment: Science and Policy for Sustainable Development, 55(3): 1428.

https://doi.org/10.1080/00139157.201 3.785864

Daget, J. 1976. Les modeles mathematiques en ecologie. Masson, Paris. Coll. Ecologie, 8: 172 p.

Dharma, B. 2005. Recent and fossil Indonesian Shells. Conchbook, Hackenheim. Germany. 424 p.

Dibyowati, L. 2009. Keanekaragaman moluska (Bivalvia dan Gastropoda) di sepanjang Pantai Carita, Pandeglang, Banten. Skripsi. Departemen Biologi FMIPA, IPB. Bogor. Hlm.: 17.

Fortes, M.D. 2012. A Review: Biodiversity, Distribution, and Conservation of Philippine Seagrasses. Philippine J. of Science. 142: 95-111.

Fredriksen, S., H. Christie and B.A. Sæthre. 2005. Species richness in macroalgae and macrofauna assemblages on Fucus serratus L. (Phaeophyceae) and Zostera marina L. (Angiospermae) in Skagerrak, Norway. Marine Biology Research, 1(1): 2-19.

http://doi.org/10.1080/174510005100 18953

Fredriksen, S., A. De Backer, C. Bostrom, and H. Christie. 2010. Infauna from Zostera marina L. meadows in Norway. Differences in vegetated and unvegetated areas. Marine Biology Research, 6(2): 189-200. 
http://doi.org/10.1080/174510009030 42461

Gamfeldt, L. and H. Hillebrand. 2008. Biodiversity effects on aquatic ecosystem functioning - Maturation of a new paradigm. International Review of Hydrobiology, 93(4-4): 550-564. https://doi.org/10.1002/iroh.20071102 2

Raso G., J.E., S. Gofas, C.S. Casanova, M.E. Manjon-Cabeza, J. Urra, and J.E.G. Munoz. 2010. El mar más rico de Europa: Biodiversidad del litoral occidental de Málaga entre Calaburras y Calahonda. Consejería de Medio Ambiente, Junta de Andalucía, Sevilla. 138 p.

Gillanders, B.M. 2006. Seagrass, fish, and fisheries. in Seagrasses: biology, ecology, and conservation. Springer, Berlin. 503-536 pp. https://doi.org/10.1007/978-1-40202983-7_21

Gratwicke, B. and M.R. Speight. 2005. The relationship between fish species richness, abundance and habitat complexity in a range of shallow tropical marine habitats. J. of Fish Biology, 66(3): 650-667. http://doi:10.1111/j.0022-1112.2005. 00629.x

Hartoni, dan A. Agussalim. 2013. Komposisi dan kelimpahan moluska (gastropoda dan bivalvia) di Ekosistem Mangrove Muara Sungai Musi Kabupaten Banyuasin Provinsi Sumatera Selatan. Maspari J, 5(1): 6-15.

Heck, K.L.Jr., T.J.B. Carruthers, C.M. Duarte, A.R. Hughes, G. Kendrick, R.J. Orth and S.W. Williams. 2008. Trophic transfers from seagrass meadows subsidize diverse marine and terrestrial consumers. Ecosystems, 11(7): 1198-1210. https://doi.org/10.1007/s10021-0089155-y
Helfman, G.S., B.B. Collete, D.E. Facey, and B.W. Bowen. 2009. Diversity of Fishes: Biology, Evolution, and Ecology. ( $2^{\text {nd }}$ ed.). Wiley-Blackwell: John Wiley and Sons Ltd. Chichester. UK.737 pp.

Hily, C., S. Connan, C. Raffin, and S. WyllieEcheverria. 2004. In vitro experimental assessment of the grazing pressure of two gastropods on Zostera marina L., epiphytic algae. Aquatic Botany, 78: 183-195.

Irawan, I. 2008. Struktur komunitas moluska (Gastropoda dan Bivalvia) serta distribusinya di Pulau Burung dan Pulau Tikus, Gugusan Pulau Pari, Kepulauan Seribu. Skripsi. Program studi Biologi FMIPA IPB, Bogor. 25 hlm.

Islami, M.M. 2012. Studi kepadatan dan keragaman moluska di pesisir Pulau Nusalaut, Maluku. Oseanologi dan Limnologi di Indonesia, 38(3): 293305.

Islami, M.M. dan Mudjiono. 2009. Komunitas moluska di perairan Teluk Ambon, Provinsi Maluku. Oseanologi dan Limnologi di Indonesia, 35(3): 353-368.

Istiqlal, B.A., D.S. Yusup dan N.M. Suartini. 2013. Distribusi horizontal moluska di kawasan padang lamun pantai Merta Segara Sanur, Denpasar. $J$. Biologi XVII (1): 10-14. https://ojs.unud.ac.id/index.php/BIO/a rticle/view/8326

Kendrick, G.A., M. Vanderklift, D. Bearham., J. Mclaughlin, J. Greenwood, C. Säwström, and A. Howard. 2016. Benthic primary productivity: production and herbivory of seagrasses, macroalgae, and microalgae. $61 \mathrm{p}$.

Keputusan Menteri Lingkungan Hidup Nomor 200 Tahun 2004. Kriteria Baku Kerusakan dan Pedoman Penentuan Status Padang Lamun. 
Deputi MENLH Bidang Kebijakan dan Kelembagaan Lingkungan Hidup.

Khanna, D.R., and P.R. Yadav. 2004. Biology of Mollusca, Discovery Publishing House, Gavya Ganj, New Delhi. 110002.

Koch, E.W., J.D. Ackerman, J. Verduin and M. van Keulen. 2006. Fluid dynamics in seagrass ecology — from molecules to ecosystems. Seagrass: Biology, Ecology, and Conservation In: Larkum, A.W.D, Orth, R.J., Duarte, C.M. (eds.). Springer, The Netherlands. 193-225 pp.

Kurihara, H., S. Kato, and A. Ishimatsu. 2007. Effect of increased seawater $\mathrm{pCO} 2$, on the early development of the oyster Crassostrea gigas. $J$. Aquat. Biol., 1: 91-98.

Kusnadi, A., T. Triandiza dan Hermawan, A. E. 2008. Inventarisasi jenis dan potensi moluska pada lamun di Kepulauan Kei Kecil, Maluku Tenggara. Biodiversitas, 9(1): 30-34.

Mendes, C.L.T., M. Tavares and SoaresGomes, A. 2007. Taxonomic sufficiency for softbottom sublittoral mollusks assemblages in a tropical estuary, Guanabara Bay, Southeast Brazil. Marine Pollution Bulletin, 54: 377-384.

Mudjiono. 2009. Telaah komunitas moluska di rataan terumbu Perairan Kepulauan Natuna, Kabupaten Natuna. Oseanologi dan Limnologi di Indonesia, 35(2): 151-166.

Mudjiono. 2007. Sebaran dan kelimpahan komunitas fauna moluska di sekitar perairan Provinsi Kepulauan Bangka Belitung. Sumberdaya Perairan Bangka-belitung. Pusat Penelitian Oseanografi-LIPI. 195-206.

Nugroho, S.H. 2012. Morfologi pantai, zonasi dan adaptasi komunitas biota laut di kawasan intertidal. Oseana, 37(3): 11-21.
Nybakken, J.W. 1992. Biologi laut, suatu pendekatan ekologi. PT. Gramedia Pustaka Utama. Jakarta. 496 hlm.

Odum, E.P. 1994. Dasar-dasar ekologi. Gadjah Mada University Press. Yogyakarta. $697 \mathrm{hlm}$.

Odum, E.P. 1971. Fundamentals of Ecology. W.E. Saunders. Philladelphia. USA. 574 p.

Orth, R.J., T.J.B. Carruthers, W.C. Dennison, C.M. Duarte, J.W. Fourqurean, K.L. Heck Jr., A.R. Hughes, G.A. Kendrick, W.J. Kenworthy, S. Olyarnik, F.T. Short, M. Waycott, and S.L. Williams. 2006. A global crisis for seagrass ecosystems. BioScience, 56(12): 987-996. https://doi.org/10.1641/00063568(2006)56[987:AGCFSE]2.0.CO; 2

Poutiers, J.M. 1998. Gastropoda and Bivalvia. The Living Marine Resources of The Western Central Pacific. Vol. 1: Seaweeds, corals, bivalves, and gastropods. Carpenter, K.E. and V.H. Niem. (eds.). Food and Agriculture Organisation of the United Nation. Rome. 686 p.

Rachmawaty. 2011. Indeks keanekaragaman makrozoobentos sebagai bioindikator tingkat pencemaran di muara Sungai Jeneberang. Bionature, 12(2): 103109.

Rahmawati, S., A. Irawan, I.H. Supriyadi dan M.H. Azkab. 2017. Panduan Monitoring Padang Lamun. Malikusworo H. dan A. Nontji (eds). CRITIC, CORMAP-LIPI. Jakarta. Hlm.: 41.

Razak, H. 2003. Penelitian kondisi lingkungan perairan Teluk Jakarta dan sekitarnya. Laporan Akhir. Pusat Penelitian Oseanografi - LIPI. Hlm.: 93. 
Riniatsih, I. dan Munasik. 2017. Keanekaragaman megabentos yang berasosiasi di ekosistem padang lamun perairan Wailiti, Maumere Kabupaten Sikka, Nusa Tenggara Timur. J. Kelautan Tropis, 20(1): 5559.

https://doi.org/10.14710/jkt.v20i1.135 7

Rueda, J.L., P. Marina, J. Urra and C. Salas. 2009. Changes in the composition and structure of a molluscan assemblage due to eelgrass lossin southern Spain (Alboran Sea). J. of the Marine Biological Association of the United Kingdom. 89(7): 1319-1330. https://doi.org/10.1017/S0025315409 000289

Ruswahyuni. 2010. Populasi dan keanekaragaman makrobenthos pada perairan tertutup dan terbuka di Teluk Awur Jepara. J. Ilmiah Perikanan dan Kelautan, 2(1): 11-20. http://doi.org/10.20473/jipk.v2i1.116 76

Septiana, N.I. 2017. Keanekaragaman moluska (bivalvia dan gastropoda) di pantai pasir putih Kabupaten Lampung Selatan. Skripsi. Jurusan Pendidikan biologi Fakultas. Hlm.: 108.

Short, F.T., E.W. Koch, J.C. Creed, K.M. Magalhaes, E. Fernandez, and J.L. Gaeckle. 2006. SeagrassNet monitoring across the Americas: case studies of seagrass decline. Marine Ecology, 27(4): 277-289. http://doi.org/10.1111/j.14390485.2006.00095.x

Short F.T., T. Carruthers, W. Dennison, and M. Waycott. 2007. Global seagrass distribution and diversity: A bioregional model. $J$. of Experimental Marine Biology and Ecology, 350(1-2): 3-20. http://doi.org/10.1016/j.jembe.2007.0 6.012
Stachowicz, J.J., J.F. Bruno and J.E. Duffy. 2007. Understanding the effects of marine biodiversity on communities and ecosystems. Annu. Rev. Ecol. Evol. Syst., 38: 739-766.

http://doi.org/10.1146/annurev.ecolsy s.38.091206.095659

Susana, T. 2005. Kualitas zat hara perairan Teluk Lada, Banten. Oseanografi dan Oseanologi di Indonesia. Pusat Penelitian Oseanografi - LIPI. 37: 59-67.

Unsworth, R.K.F., E. Wylie, D.J. Smith and J.J. Bell. 2007a. Diel trophic structuring of seagrass bed fish assemblages in the Wakatobi Marine National Park, Indonesia. Estuarine, Coastal and Shelf Science, 72(1-2): 81-88. http://doi.org/10.1016/j.ecss.2006.10. 006

Unsworth, R.K.F., J.D. Taylor, A. Powell, J.J. Bell, and D.J. Smith. 2007b. The contribution of scarid herbivory to seagrass ecosystem dynamics in the Indo-Pacific. Estuarine, Coastal, and Shelf Sciences, 74: 53-62.

Urra, J., Á.M. Ramírez, P. Marina, C. Salas, S. Gofas, and J.L. Rueda. 2013. Highly diverse molluscan assemblages of Posidoniaoceanica meadows in the northwestern Alboran Sea (W Mediterranean): Seasonal dynamics and environmental drivers. Estuarine, Coastal and Shelf Science, 117: 136-147.

https://doi.org/10.1016/j.ecss.2012.11 .005

Vaghela, A. and R. Kundu. 2011. Spatiotemporal variations of hermit crab (crustacea: decapoda) inhabiting rocky shore along Saurashtra Coast, the western part of India. Indian $J$. of Marine Science, 41(2): 146-151.

Vaghela, A., B. Poonam, and R. Kundu. 2013. Diversity and distribution of intertidal Mollusca at Saurashtra 
Coast of Arabia Sea, India. G.J.B.B., 2(2): 154-158.

Vonk, J.A., M.J.A. Christianen and J. Stapel. 2010. Abundance, edge effect, and seasonality of fauna in mixed-species seagrass meadows in southwest Sulawesi, Indonesia. Marine Biology Research, 6(3): 282291.

https://doi.org/10.1080/17451000903 233789

Wood, H.L., J.I. Spicer and S. Widdicombe. 2008. Ocean acidification may increase calcification rates but at a cost. Proceeding Biology Sciences. 7
Agustus 2008, London. 275(1644): 1767-1773.

https://royalsocietypublishing.org/doi/ pdf/10.1098/rspb.2008.0343

Yuniarti, N. 2012. Keanekaragaman dan distribusi bivallvia dan gastropoda (Moluska) di pesisir Glayem Juntinyuat, Indramayu, Jawa Barat. Skripsi. Program studi Biologi FMIPA IPB, Bogor. Hlm.: 27.

\author{
Received : 22 May 2019 \\ Reviewed : 24 May 2019 \\ Accepted : 05 December 2019
}

